\title{
Formation of Roman Law in Monarchy
}

\author{
Robertas Pukenis \\ Vytautas Magnus University, Kaunas, Lithuania
}

\begin{abstract}
Monarchy has started with the establishment of the city of Rome in 753 B.C. and lasted until 510 B.C. Having settled on Seven Hills, Romans found here local inhabitants and their civilisation which was marked by pagi (the composition of a settlement), gentes (families), and clients belonging to it. Romans have strengthened the institute of a family without abolishment of relations between gentes. The date of city foundation was when the first king Romulus organised the society of the city by dividing it into patricians and plebeians. In Monarchy, when Etruscans have implemented reforms, Rome has expanded from a city to a state. In 6 A.D., sacred rites involved a primitive Roman law. At international level, in words of nowadays, the Law of Fetial taken over from other nations and appreciated by Romans in practice has been functioning. It lasted for eight centuries. Law is analysed with the attempts to determine its impact on culture. How did the developing law of Rome manage to influence the culture of other nations? "In Rome, script appeared in 6 A.D.". the city of Rome. Leges regiae has been restored from other documents. More historical monuments, witnessing about the culture of the city of Rome, have been remained.
\end{abstract}

Keywords: monarchy, culture, a gente (a family), law, king

The aim of the paper is to describe the initial stage of Roman law, when the city of Rome was established, in the most precise way. Legal-historical method is applied as it is hard to understand legal systems without history. The object is connected with Roman traditions, legal acts of those in power and the decisions of the assemblies of the nation. Roman law has also been analysed in the context of culture. Law brings impact on human culture. In Roman Empire, law helped nations to integrate into the life of the city and later, into the empire. What is culture? Lots of various definitions exist: Culture is the characteristics and knowledge of a particular group of people, defined by everything from language, religion, cuisine, social habits, music and arts. The centre goes a step further, defining culture as shared patterns of behaviours and interactions, cognitive constructs and understanding that are learned by socialization. Thus, it can be seen as the growth of a group identity fostered by social patterns unique to the group. The word "culture" derives from a French term, which in turn derives from the Latin "colere", which means to tend to the earth and grow, or cultivation and nurture. "It shares its etymology with a number of other words related to actively fostering growth" features covering the sublime of human life and behaviour, relations with others, family and environment. Certainly, 1,300 or 1,000 years ago, a different understanding of culture existed as the relations among humans

Corresponding author: Robertas Pukenis, Doctor of Church and Civil Law, Doctor of Italian Civil Law and Lic. of Theology, docent, Department of Public Administration, Faculty of Political Science and Diplomacy, Vytautas Magnus University, Kaunas, Lithuania; research fields: the Law of European Union and Comparative Constitutional Law. E-mail: rev.pukenis@takas.lt.

${ }^{1}$ N. A. Maškinas. Senovès Romos istorija (The history of ancient Rome). Vilnius. 1952, p. 9.

${ }^{2}$ Kim Ann Zimmermann. What is culture? Definition of culture. February 19, 2015. Retrieved from http://www.livescience.com/ 21478-what-is-culture-definition-of-culture.html. 
have been different. Despite time being, law has always been influencing the culture of nations. It is necessary to determine the scope of the influence. It might have been that Romans have taken over the habits from other nations or other nations have been forced to become part of Roman Empire. Thus, the validity and functioning of legal norms, the response of nations, the acceptance of rules of Roman life, the subjugation of neighbouring nations into Roman Empire are the scopes of this analysis. The same is with the travellers from other countries (peregrini) used to accept the rules of life style of Romans or, in other words, how law joined neighbouring nations into Roman Empire. There were various events: wars, agreements, and peaceful surrender to Roman will. It serves as if a new way to have a look at the relation of Roman law to culture. Very little legal sources about monarchy remained. Roman culture is much more depicted. True, the context of the object is also limited and it is no way to analyse the culture of other nations. The discussions can be only about assimilation of Roman law, subjugation or enslaving of neighbouring countries.

\section{Seven Hills of Rome}

Roman law has started with the founding of the city of Rome on Seven Hills. The city of Rome did not start on an empty field by putting on the tents but by involving the nations being here. "Rome is founded when Latin community is united with Sabine one. Since the very beginning of the city, Etruscans also take part in the life of the city"3. Having occupied news areas, Rome often used to take over the best cultural features, habits of these small nations. The oldest Italian tribes which have existed before 2 B.C. were the Ligures, residing in the north of Italy, the Sicels, the Sicani, and Italic tribes, the Sabeli, Umbrians, Oshia and Latins ${ }^{4}$. It is hard to prove the abundance of nations. Some say that they came from the Alps, others-they moved from Greece and thus, mingled with locals. A famous historian T. J. Cornell proves: The first traces of permanent habitation on the area of Rome date back to around 1,000 BC, and consist of a handful of cremation graves in the forum ${ }^{5}$. Migration of nations remains a hypothesis for science. It might have been in one way or the other: They might have come from somewhere else. Rome, the Seven Hills of Rome is a wonderful place attracting people of other nations. Having settled here Romans found here the villages (pagi) of local inhabitants, the settlements united by common interests, cultural and religious traditions, blood relations among inhabitants ${ }^{6}$. Pre-Roman civilisation is characterised by: pagi, gens and famiglia (family). Gens was a group of many families, the members of which differed from other gens by a common name of a gen-nomengentilicium. Such a relationship was without any grades as common ancestors were rather remote and due to the reason that there were no grades. Romans have developed the institute of a family without abolishing the relations between relatives (gens). In historical times, the family, not the gens, was the basic unit of Roman society ${ }^{7}$. Clientela is not a historical "finding". It is common for Latin, Sabine, Etruscan and Eleni, German and Slavic nations.

The word "client" is derived from clinare and means devotedness, obedience to patrons. Clients usually were poor guests or those who have been driven away due to debts or any other crime. Clients made a large

\footnotetext{
${ }^{3}$ N. A. Maškinas. Op. cit., p. 93.

${ }_{5}^{4}$ Consult N. A. Maškinas. Op. cit., 1952, p. 71.

5 T. J. Cornell. The beginnings of Rome. Italy and Rome from the Bronze Age to the Punic Wars (1,000-264 BC). London and New York. First published in 1995, p. 48.

${ }^{6}$ Such tutorials of Italian Romanists present a common statement of no doubt, even if it is over 1,400 years old. Manuali giuridici. Nr. 17. Storia del diritto romano (The History of law Rome). Edizione Simone. 1993, p. 18; The Cultural Atlas of the World. The Roman World. Oxord Ltd. 1991. Op. cit., p. 19.

7 The cultural Atlas of the world. The Roman world. Op. cit., p. 19.
} 
group of a society after the tribes ${ }^{8}$. Having become stronger, monogenic patriarchal family separated from the order of communal tribe. Family differs from a tribe:

(1) An ancestor of a family is real while the one of a tribe - mythical;

(2) The relations between relatives of a family are gradual and this is different from a tribe;

(3) A family is based on the authority of a father; a tribe is based on community relations and solidarity;

(4) Family cult has been provided to ancestors and the tribe used to worship the Gods of Olympus;

(5) The name of a family added to the first name in Roman system of names describes a gen ${ }^{9}$. The name of a family is an external sign pointing at dependency on the main community clan group. It is united by equality of all members and a deep spirit of solidarity. Sacred things and cemeteries of a gen have been common. Land has been cultivated together, common cemeteries meant unity of a clan. Clientes also belonged to gentes. A nickname which is inherited and appears later than a name identifies a gen. So, having come by Seven Hills, Romans have already found an existing civilisation of local nations. The date of establishing of the city of Rome is when Romulus, the first Roman King, has divided the society by providing royal laws-leges regis ${ }^{10}$. As the Roman tradition says, patricians originate from the first 100 senators. They are the noble citizens of Rome while plebeians are the poor ones. Already, the first king Romulus indicated a primary duty to defend the city of Rome. Patricians used to occupy leading positions in the army. Due to this, territorial administrational division has been implemented with the aim to recruit the army in case of danger as soon as possible. Servius Tullius ordered the citizens to have guns. The system of pagi settlements became well-fixed. It served for Roman defence purposes and for their household.

There were quarrels between patricians and plebeians as the latter had to take part in wars and have not been allowed to be present in management. Marriages of patricians and plebeians have been forbidden. The historians are firmly sure that Romulus has divided tribes into three tribu units: Ramnies, Tities, Luceres ${ }^{11}$. The majority of historians state that the name Romans originate from Ramnies. These tribes gave a bit different base for the forming of neighbouring nations: Latini (Latins), Sabini (the Sabines), and Etruschi (the Etruscans). In such a way, a community was born with a complex of rules regulating the relations between persons and institutions, able to force the members of the community to keep them. This also illustrates that already in the beginning, the fight and blending among nations take place. Finally, culture of a now society is formed. It even marks a different historical period, monarch Rome: From Latin-Sabine, there is a transformation into Latin-Etruscan phase.

\section{Institutions and Archaic Law}

Monarchy is divided into Latin-Sabine period (8 B.C.-7 A.C.) under the rule of four kings and during Latin-Etruscan phase (6 B.C.-4 A.C.) under the rule of three kings. During monarch period, the laws of kings prevailed (leges regum). The king was the head of a city, a military leader, and the one who observed the order in the city. All had to conform the will of Gods. A famous Italian Romanist states that "An ancient Roman

\footnotetext{
${ }^{8}$ Consult about clients, Nr. 17. Storia del diritto romano. Op. cit., p. 28.

9 Consult the definition of a tribe in the tutorial, Nr. 17. Storia del diritto romano. Op. cit., p. 26.

${ }^{10}$ Leges Regiae, Romulus, Leges Regiae. Laws of the Kings (753-509? BC). http://droitromain.upmf-grenoble.fr/Leges/ leges_regia_Riccobono.htm (See January 14, 2016): Patricii sacerdotiis et magistratibus fungerentur et iudicarent, plebei ueroagros colerent et pecusalerent (Translation). Clergymen and magistrates have been elected from the Patricians. They had to fulfil the duties and judge. Plebeians had to work in fields and breed sheep.

${ }^{11}$ Consult. Storia del diritto romano. Op. cit., p. 19. The Cultural Atlas of the World. Op. cit., p. 18.
} 
system before Christianity and in times of Christianity, does not accept the right of separation from morality religion" ${ }^{\prime 2}$. Military leaders (magister equitum) have been appointed by kings and later by the Senate as well. The National Assembly (comitia curiata) discussed declarations of war, military defence but the final word belonged to the Senate. According to Roman traditions, in the beginning, it had 100 members and later, by the end of Monarch Period, there were 300 senators. The Senate used to approve the decisions of National Assembly. It has slowly taken over the implementation of foreign policy. Thus, this institution had a direct link with people of other nations.

During Etruscan period, the King Servius Tullius has done a military reform exercitus centuriatus which was of revolutionary importance. It finished the transformation from a city to a state. The reform has encouraged the establishment of a new commercial activity, family communities, located outside the city. They have been committed to cultivate the land and take up some crafts. Citizens have been divided into classes and Rome was split into territorial tribes. There were four belonging to a city, the other 12 were rural. Society has been compiled in accordance to Etruscan pole, by dividing into two groups: aristocrats and slaves with clients (it is a separate group of people having their own separate patrons or benefactors). Slaves have been considered capture of war. Thus, slaves mainly were people of different nations, though there were cases when the one who had a debt and have not returned it, had been judged for slavery at the creditor. There were three types of National Assemblies or Comitium (comitia). The most important were the Comitium of Centurions, assemblies founded by Etruscan king Servius Tullius. They have started their existence since 6 B.C. and lasted until 4 B.C. Military political character prevailed in the division of the army. The public has been split into five classes. The first division category was in accordance to age: centuriae iuniores from 18 to 45 , and the senior - from 45 to 60 years old. In total, the citizens have been divided into 193 centurions $^{13}$. Every class had a certain ammunition. The first class (the rich) was required to have full ammunition (helmets, a round shield, bronze armour of feet and body, a spear and a sword). There were less requirements from the citizens of other categories. The fifth class was just required to have slings and the reserves of stones ${ }^{14}$. In centurions, original voting in accordance to richness existed. It was voted by centurions (comprising of soldiers in respect to their property status - in one hundred, each had one vote. One of the main powers of centurion comitiums was to approve laws (leges). The other kind of comitiums was the comitiums of tribes (comitia tributa). These were the assemblies where territorial tribes used to vote. All adults from cities and villages could be invited to comitiums of tribes. A consul or a praetor used to invite them. By the end of a Monarch Period, these centurions turned into political assembly more: election of magistrates, consuls, voting for a law, approval of a war, death penalty for citizens. It was similar to a House of Men where laws and important events, the questions of the nation: Family, cult, war, works connected with the welfare of the city were discussed. It also approved wills.

Only patricians participated in Comitia Curiata $^{15}$, the Comitiums of Curia and they used to vote in neighbouring unions-Curia. A magistrate, possessing the power of imperium, used to invite them to

\footnotetext{
12 P. Catalano. Diritto e persone. Studi su origine e attualità del sistema romano (Law and persons. The study about origin and the importance of Roman system). I. parte. Torino. 1990, pp. 8-9. Il Sistema romano antico, sia precristiano sia Cristiano, non conosce l'isolamento del diritto rispetto alla morale e alla religione.

${ }_{13}$ Consult about centuriae, Nuovo dizionario giuridico romano a cura Federico del Giudice-Sergio Beltrani (Contemporary Dictionary of Roman Law). 2 edz., p. 91.

${ }_{14}$ Consult about military reform, V. Arangio-Ruiz. Storia del diritto romano. Op. cit., p. 15.

15 Nuovo dizionario giuridico romano. Op. cit., pp. 107-108.
} 
Campidoglio and had sacral functions. These were the only, oldest comitiums during Monarch Period. After the reforms of Servius Tullius, they became useless. Later, by the end of Monarch Period, these assemblies did not attract people at all and just symbolic rites, e.g., adrogatio, when a parent of a family adopts a son or a daughter without parents or parents who cannot give a birth to a child adopt babies in participation of Pontifex Maximus (Senior of Clergymen College appointed by the king and later by the emperor). These were the functions of the third institution - the National Assembly which has already functioned in the early period of Rome after the king and Senate ${ }^{16}$ ruling.

\section{Fetiales}

This kind of law which has been taken by Romans from other nations existed for eight centuries and was used as if international law. The Fetial board consisted of 20 priests, presided by the chairman (pater patratus $)^{17}$. This board did not have the right to solve the matters about military actions. In monarchy, this function has been performed by a king in coordination with the Senate. Military type laws used to be called leges bello indicendo (laws in military actions). In case of violation of Roman rights by its neighbours (stealing of animals, bad behaviour with people, occupation of meadows, cheating in trade), pater patratus approached the border and solemnly announced, "audi Iupiter, auditre fines, audiat fas: ego sum publicus nuntius populi romani, legatus venio, verbisque meis fides sit" (Listen, Jupiter, listen, the lands, let everybody hear: I am the messenger of the Roman people, coming as a legate, my words are to be trusted). This solemn formula meant: Return back what you had taken, repair the harm made to the Romans or, you shall be assaulted and decimated or enslaved. In 30 days, the same pater patratus would arrive to see if the just demands were fulfilled; if not, then in the name of the king, he declared war. Thus, military actions have been called iustum bellum-fair war. When Romans encircled settlements, they have presented the ultimatum to give up, and if the latter agreed, local inhabitants received rights as well, e.g., trading, later marriage with Romans. The formulas of solemn war announcing used to fix a formal justification of war. These orders come from the Monarchy period ${ }^{18}$. War in the consciousness of Romans has been justified if Roman interest had to be supported or to punish the aggressor. The saying bellum pacis est causa (a war is a reason of peace) discloses the tactics of Romans. Though, the main idea they have been keeping was protection of peace and it was the condition for the development of nations.

Fetial law is simply a part of war and peace law. Romans had the following formula: Ius belli et pacis (A War and Peace Law) points at the behaviour of Romans during war and peace period ${ }^{19}$. Today, it would correspond to humanitarian law. This Collegium is as if the one serving as Protocol Department of Foreign Affairs Ministry. Thus, it existed until the second century, becoming a purely protocol part of the Senate. Romans possessed the principles of a fair war and allowed enemies to escape military actions by improving the situation. This is a war culture. Since the very beginning of the city of Rome, Romans had the concepts of a fair and unfair war. This was also a special relation of Romans and other nations during war time ${ }^{20}$.

\footnotetext{
${ }_{16}$ Consult about Centurias, T. J. Cornell. The beginnings of Rome. Op. cit., pp. 179-181.

17 Nuovo dizionario giuridico romano. Op. cit., p. 205.

${ }_{18}$ Consult Leges Regiae. Ancus Marcius IV, 1. Op. cit.

${ }^{19}$ Consult P. Catalano. Diritto e persone. Op. cit., p. 18: non avevano alcun patto con i Romani, avevano conchiusa una pax (There was not any agreement with Rome but peace has been proclaimed).

${ }^{20}$ Consult about Fetial Law, Lineamenti di storia del diritto romano sotto redazione M. Talamanca (Historical features of Roman law). Milano. AA. VV. Editore: Giuffrè. 1979, pp. 27-28.
} 


\section{Sacredness of Legal Rite}

Monarchic period is characterized by the domination of codified pontifical boards. Sacer ritus is a set of judicial norms prescribed to regulate the relationship between human beings and deities. According to Romans, pontifical representatives have been compiling a calendar where the days for working, meetings had been indicated. The second king Numa Pompili was a very pious king, who presented himself as a mediator between god and people. The kings had to accomplish the following functions: to know the will of God and apply it in public life, to explain the will of gods to people. After the death of the king, the Senate used to pray for accomplishing the will of gods and electing another good ruler. This period was called interregnum. Pontifical boards performed the function of augures, i.e., they prophesied the future, especially the outcome of battles. There were two magistrates (duoviri sacris faciundis) responsible for storing sealed books and pointing out the reasons for the judicial decision at magistrate's request. Special respect has been devoted to Roman vestals - virgins. The third institute of management beside the king and the Senate was the National Assembly where the laws and major events were discussed. Thus, we can see how sacer ritus determined the sacred character of the city-state of Rome, its socio-political organization; it was rather genial for those times, greatly improved by military, administrative, and political reforms that were carried out by Etruscans ${ }^{21}$. The rite of law is one concept, totally different from the cult of Roman religion which has been famous for the offers of animals, birds, and fruit to gods, long prays but not the emotional ecstasy. Praying for a Roman was a magic tool to influence Gods for their own benefits. They had gods of relatives. Roman religion did not have ethical norms. Romans have taken some features of totemic religion from Italic nations. This is well reflected in the legend about a she wolf, the one who sucked the future founder of Rome.

\section{Ius Quiritium and Family Law}

Monarch period has existed for 243 years and ius Quiritium — for four centuries. Ius Quiritium is perceived as a private civil law (in terms of nowadays) comprised of habits. It is a legal regulation between noble Roman families which have been ruled by a father (pater familias), but that was not a family law. It has not regulated internal relations of a family. It was a personal Roman law which is the most archaic and compiled of the unwritten habits of ancestors, transferred "mouth-to-mouth". It covered the questions of a family, marriage, patria potestas, and private ownership. Duties have not been indicated there. In archaic period, they have not been legally determined. Patria potestas is a power taken by Romans from other nations. It is very much cultural and accepted by the nation. (All nations of Barbarians used to accept the power of males and their right to decide on the matters of life or death of a wife or children). Patria potestas is acquired with the birth from a legal marriage (when a son marries and a daughter in law comes into a family) and adoption (a father adopts a son). Refusal of adoption (adrogatio) took place when a son became adult, in case of death of a father or father's capitis deminutio, the authorities of a father became less. Roman patria potestas means the care of a wife as one's own daughter and care of a daughter in law as one's own child. At that time, it was a form of marriage, matrimonium cum manu ${ }^{22}$. Despite of the fact that sons and a family were the citizens and possessed all political rights, they had to obey a father fully. The latter had:

(1) Ius exponendi - the right to eliminate the descendants (let them die) or to bring them up;

${ }_{21}$ Consult about pontifical boards, (I college sacerdotali), Lineamenti di storia del diritto romano. Op. cit., pp. $26-27$.
22 About the kinds of marriage, I. Nekrošius., V. Nekrošius, St. Vèlyvis. (Roman Law). Vilnius: Justitia. 1999, p. 159. 
(2) Ius vendendi - the right to sell them, e.g., to give away a child to another family for a debt;

(3) Ius vitae ac necis - the right to kill one's supervised persons or let them live. These cruel rights were valid in the first period and during the Republic Period, the Law of Family acquired more features of love and respect to life ${ }^{23}$.

The word nuptiae (engagement) meant the wedding ceremony and matrimonium the status, reason and aim of a person as such. The functional features of marriage in bringing new life depended upon the interests of a family. If in the beginning, marriage was left for the relations among groups, later, the state started regulating it to expand, make narrow or transform the area of wedding exchange. Archaic family used to appreciate the unborn life and the descendant used to represent the heritage of a family but not of a separate individual. In such a context, dowry is the factor of functionality which makes marriage easier ${ }^{24}$. There was an understanding of a legal family in Archaic period: Matrimonium iustum, a legal marriage had to correspond the following conditions: capacity to marry (conubium), maturity, agreement of those going to marry sui iuris, or relatives, if they were alieni iuris. At that time, there were three forms of marriage making. Confarreatio means marriage in religious way as if the Goddess Dial would bless it in presence of 10 witnesses, accompanying the couple with torches. A newly wedding couple used to break a slice of bread symbolizing a common life to honour Jupiter. It was a solemn, aristocratic form of marriage used only among patricians. The other primitive form which remained with minor changes until Classic period was coëmptio. According to this form, a female, possessing her rights (sui iuris) or depending on her father (pater potestas) is taken care by her husband, if the latter has sui iuris. If the one does not possess the rights, then his wife belongs to the one who cares about the husband pater potestas, a father taking care of the husband of a fiancee. Certainly, she used to live with her favoured one but legally her property belonged to the one who took care of her husband. This was a must due to property relations. This form could have been used (coëmptio fiduciaria) without any marriage, e.g., a woman did not want to marry the man whom she has not loved, then she usually used to choose (coëmptio fiduciaria) an elderly male who took care of her property. The involvement of a woman into a family of a man took place in the way of usus, most widely spread among people of other nations. In such a case, a male or the one who took care of a male (pater potestas) used to live with a future wife for a year and this life has been legalised by a marriage, except the case when a woman left home for three nights (trinocti usurpatio) with the intention to break marriage. Thus, these three forms mean matrimonium сum тапи, a certain legal limitation of a woman in the fields of inheritance and property. Even if a female was sui iuris, and she marries a male sui iuris, property matters are still managed by her husband. If a husband himself does not possess these rights, then the property of a daughter in law belongs to the farther in law. At convention manuum, a girl used to be included into a family of a husband ${ }^{25}$. A wife (uxor) used to take care of household chores already in Archaic period.

A Roman family was a complex of property of persons, slaves and all the taken care of (clientes). The head of it is pater in domus - "an absolute ruler". Roman family is patriarchal, authoritarian, agnatic group of persons united by the relationship of a father's side. A family used to be supported by monogamy marriage to guarantee descendants and inheritance. Thus, a female's fidelity was compulsory and legal. Patria potestas used to preserve a Roman family unified for centuries, especially when females were under the supervision of

23 Consult about pater familias, Nuovo dizionario giuridico. Op. cit., pp. 403-404.

24 Consult about confarreatio, coëmptio and other forms of marriages. I. Nekrošius. Op. cit., pp. 162-163.

25 Consult about property relations of a woman, V. Arangio-Ruiz. Istituzioni del diritto romano (The Basics of Roman Law). Napoli. 1991, pp. 458-459. 
males. A husband could have left a wife in three cases: In case of abortion, infidelity from a woman's side or a man has been humiliated by a wife, e.g., when a wife has taken a key from a wine cellar and drank with a slave. Such Roman families have been established in the whole empire without any limitation of habits for the marriages of other nations ${ }^{26}$.

The following concepts of relative relations started prevailing in archaic Roman family: Adgnatio-it is a civil relationship through a male ancestor, having juridical consequences in case of inheritance, security, care, and sale. After the death of a family father, all agnates make a family of a common law (familia communi iure). There were cases when after the death of a father, common inheritors continued to protect the unshared inheritance, though everyone was the owner of one's part. Such a form of a community which appeared due to economic and political motives, and providing the possibility to remain in a dead class, has become even stronger by the end of Republican regime. Cognatio - it is a natural relationship through a female ancestor. Blood relation in archaic law was just an obstacle in marriage and it was rather important for cult matters. Juridical consequences have been increasing in the time run when at last, Justinian has equalised cognatio with adgnatio.

In Roman law, family habits (mores) were extremely strong. The assimilation of strangers in making families, having in mind the impact of patricians in public life, was practically invalid in archaic period. The word conubium simply meant the right to marry. In forming a family, Romans implemented the protection of a Roman family from assimilation with other nations. Only in 445 B.C., lex Canuleia provided the plebeians ius conubium (the right to make a matrimony) with patricians. In Classic period, conubium was valid among all the citizens of Rome.

\section{Conclusions}

Though the entire law of Monarch period has not been covered due to the limitation of the scope of the paper, but in concluding this introductory paper, the following thoughts come out. In ruling of Servius Tullius, Rome became a city-state. It was rather weak and people wishing to protect the city constructed defence walls. It was the main point of a future empire which will become caput mundi (the world capital) in the middle of the Republic period.

In Monarch period, the base of Roman law has been put. The traditions of a nation preserved by the Pontifical Collegium have been formed. Ancient Roman law was sacral also due to the respect to law, to keeping of it. It acquired such a character that even kings obeyed the will of God.

Law has been divided into fas (orders of Gods, fulfilling of their will) and ius. This category covered the orders of kings and laws, court decisions (comitia curiata). Fas also included the sphere of international affairs, penalties for criminal crimes, marriage, various agreements, and the division of land. The concept of a family, having in mind that we are almost 3,000 years ahead, was of high spiritual level. Since 6 B.C. until the collapse of Roman Empire, the main idea of the birth right was perceiving a human being as an intelligent and social being who is provided with a positive law based on the concepts of goodness of the birth right. The concepts of birth law have been taken from Greek philosophy as Greek poets, sages, just at the birth of Rome, already had a high level of culture and philosophy. Omer (8 B.C.), Heraclitus (6 B.C.) wrote about an eternal law and considered law was the present of God. Romans have taken over the forms and expressions of Greek Hellenistic thought,

${ }^{26}$ Consult about a family, Nuovo dizionario giuridico romano. Op. Cit., pp. 349-350. 
prescribing them legal logical thought. Roman kings ruled the inhabitants of the city in religious context. Legal norms have not been separated from moral ones. It is too early to discuss about some relation of national cultures. Roman culture possesses the roots of Etruscan culture. In 510 B.C., a rebel started. Having driven away the King Tarquinius Superbus, Monarchy has been finished. Smart legal solutions in preserving of a family institute, territory management and relations with other nations in using the law of Fetial is really obvious. The Great Pontifex Publius Mucius Scevola has published 80 books by naming them Annales Maximi. According to Cicerone, these books have been started since the foundation of Rome ${ }^{27}$. Due to smartness of Roman law, it should be presented in the faculties of all world universities in a compulsory way.

\section{References}

Arangio-Ruiz, V. (1991a). Istituzioni di diritto romano (The basics of Roman law) (14th ed.). Napoli: Casa editrice dott. Eugenio Jovene.

Arangio-Ruiz, V. (1991b). Storia del diritto romano (The history of Roman law). Napoli: Casa editrice dott. Eugenio Jovene.

Catalano, P. (1990). Diritto e persone. Studi su origine e attualità del sistema romano (Law and persons. The study about origin and the importance of Roman system Part I). Torino: G. Giappichelli editore.

Cornell, T. J. (1995). The beginnings of Rome. Italy and Rome from the Bronze Age to the Punic Wars (1,000-264 BC). London and New York. First published.

Cornell, T., \& Matthews, J. (1991). The cultural atlas of the world: The Roman world. Oxford Ltd. Copyright Andromeda. Editor Graham Speake.

Del Giudice, F., \& Beltrani, S. (Eds.). (1995). Nuovo dizionario giuridico romano (Contemporary dictionary of Roman law) (2nd ed.). The Printing House Simone.

Leges Regiae. AncusMarcius (640-616). (1941). Leges regiae. Laws of theKings (753-509? BC). S. Riccobono, Fontes iuris Romani antejustiniani (Roman law sources of pre-Justinian times). Retrieved from http://droitromain.upmf-grenoble.fr/ Leges/leges_regia_Riccobono.htm

Leges Regiae, Romulus (753-716). (1941). Laws of the Kings (753-509? BC). S. Riccobono, Fontes iuris Romani antejustiniani (Roman law sources of pre-Justinian times). Retrieved from http://droitromain.upmf-grenoble.fr/Leges/leges_regia_ Riccobono.htm

Manuali giuridici (Legal manuals) No. 17. (1993). Storia del dirittoromano (The History of law Rome). Edizione Simone.

Maškinas, N. A. (1952). The history of Ancient Rome. Kaunas: The Printing House of Political and Science Literature.

Nekrošius, I., Nekrošius, V., \& Vèlyvis, St. (1999). The Roman law. Vilnius: Justitia.

Talamanca, M. (1989). Lineamenti di storia del diritto romano (The features of Roman law). Milano: Giufrè editore.

The Lithuanian encyclopaedia. (2007). Vilnius: The Institute of Science and Encyclopaedia.

Zimmermann, K. A. (2015). What is culture? Definition of culture. Retrieved from http://www.livescience.com/21478-whatis-culture-definition-of-culture.html

${ }^{27}$ N. A. Miškinas. Op. cit., p. 10. 